Folklore 125 (December 2014): 267-285

http://dx.doi.org/10.1080/0015587X.2014.947858

RESEARCH ARTICLE

\title{
At Least Two Concepts of Culture
}

\author{
Inkeri Koskinen $^{1}$ \\ Abstract \\ This article uses ideas developed in the philosophy of science to examine two concepts of \\ culture used in contemporary folkloristics. One of them appears mainly in the context of \\ archival work, while the other occurs chiefly in discussions on themes such as identity \\ politics and ethnic minorities. The main difference between the two concepts is that one \\ is used when formulating 'substantial theories' related to 'kinds', whereas the other is a \\ bone of contention in ongoing debates on the level of 'grand theories'. Theoretical tools \\ developed in earlier cultural research are taken into use in contemporary cultural \\ movements, and this affects theoretical debates on the level of grand theories.
}

\section{Introduction}

This paper examines the use of the concept or concepts of culture in contemporary folkloristics, from the viewpoint of a philosopher of science. Although folklorists use the concept of culture, in the discipline's theoretical discussions over the past few decades 'culture' has received less attention than the concept of tradition, and lately heritage. On the other hand, the concept is a notoriously debated one in anthropology (Kroeber and Kluckhohn 1952; Kuper 1999; Risjord 2007). It is entangled in several disputes that range from national politics to epistemology; politics and philosophical problems are tightly intertwined in the academic discussions where the concept is used. It is easy to agree with Christopher M. Hann's words: 'Both inside and outside anthropology, culture has long been an "essentially contested concept"' $(2002,259)$. It might be opportune to say that there are several concepts of culture, and the boundaries between them are unclear. These concepts are used not only in anthropology, but in many disciplines falling under the umbrella of cultural research, including folkloristics. In addition, during the last few decades 'culture' has gained political weight among many of the minorities that these disciplines study, and the concepts used by researchers intermingle with political ones. Folkloristics has a particular viewpoint on these political movements, because it has strong historical links to nationalism. As a philosopher of science I find 'culture' in folkloristics a fascinating example of the kind of concepts that are used in the humanities today.

It would be too immense a task to attempt to give an overall picture of the concepts of culture used by folklorists. When starting to work on the subject, I had in mind a specific concept and a theoretical debate related to it. As I am not a folklorist, I felt the need to make sure that what I wanted to say was relevant in the context of folkloristics; so I decided to gather some data. As a result, this paper concentrates on the analysis of two concepts of culture found in a limited sample of texts: eighty-three journal articles from two Finnish journals and eight doctoral dissertations from the University of (C) 2014 The Folklore Society 
Helsinki. All of the studied texts were published in Finland during the first decade of the twenty-first century. One of the concepts analysed is the one I expected to find; the other I encountered when studying the texts.

No concept of culture is problematized to any great extent in the articles or the dissertations; the word is simply used. This makes the analysis relatively easy, as it has not been necessary to compare definitions of a concept with the ways in which it is actually used. As the word 'culture' is used abundantly and in many ways in the texts, one could probably identify dozens of slightly different concepts of culture. However, the criterion used in deciding whether a case involves one or more concepts of culture is the following: if a dispute concerning culture can be resolved by differentiating culture 1 from culture2, there are two concepts. If such a dispute cannot be resolved in this way, there is but one concept.

I will start by presenting the sample of texts and the tool used to study them. I then proceed to the preliminary findings, after which I concentrate on an analysis of the two concepts. I will defend the claim that the main difference between the two concepts is that one is used when formulating 'substantial theories' related to 'kinds', ${ }^{2}$ whereas the other is a bone of contention in ongoing debates on the level of 'grand theories' (Merton 1968). In other words, one of the concepts is used in theories that make substantial claims about specific groupings (for instance, local genres), and the other is used in debates around theories that involve large-scale ontological claims.

Finally, I briefly discuss the exceptional position of folkloristics in these debates. The current grand theory-level debates and tensions regarding the concept of culture are related to an important change in the research subject of much cultural research. People whose cultures used to be studied by anthropologists, folklorists, ethnologists, and so forth, are now reviving their cultures and cultural identities, and even conducting research on their own cultures. These contemporary cultural movements resemble the cultural movements that led to the building of several European nation-states 100-150 years ago. Folkloristics as a discipline took part in the nation-building of those days, and in Finland the role of folkloristics was particularly important, as Finnish oral poetry and the national epic Kalevala had a significant role in the building of the Finnish national identity. Contemporary folklorists study cultural movements that resemble processes in which the discipline took an active part a century ago. This gives folkloristics an exceptional and potentially valuable position in the current grand theory-level debates.

\section{The Texts and the Tool}

The texts studied in this paper are mostly from two Finnish folklore journals: all research articles published in the Folklore Fellows' Network bulletin from 2000 to 2009, and all research articles published in Elore during the same period. The Folklore Fellows' Network bulletin is the journal of Folklore Fellows, an international network of folklorists supported by the Finnish Academy of Science and Letters. Elore is the journal of the Finnish Folklore Society. In addition, I have used eight doctoral dissertations in folkloristics, which were defended at the University of Helsinki during the same period.

My sample of texts is imperfect in many ways. Most, but not all, of the texts are written by Finnish folklorists, but the authors naturally participate in international discussions. In the study of academic research, which is intrinsically international, 
a national framing is inevitably artificial. However, I believe the sample is sufficient both to show that the concepts I analyse are used in contemporary folkloristics, and to shed light on the ways in which they are used.

The material is limited, but nevertheless the quantity of text was considerable, and I needed a simple way to pinpoint the most important concepts of culture used in the studied texts. I decided to concentrate on the word 'culture' and its Finnish equivalent kulttuuri, thus leaving aside the question of whether there are implicit concepts of culture that these words do not cover. However, I had to alter this decision slightly. The articles are written either in English or Finnish, and all of the dissertations are in Finnish. As the two languages differ greatly from each other, Finnish not being an Indo-European language, their comparison is at times difficult. Searching only for 'kulttuuri' and not kulttuurinen (the rough equivalent of 'cultural') without losing sight of several important compound words and idioms in one or the other language proved to be problematic. I therefore decided to include 'kulttuurinen' and all of the compound words, and to search not just for 'culture' and 'cultures' but also for 'cultural' in the English-language journal articles as well.

The freeware concordance program AntConc facilitated the study of the texts. ${ }^{3}$ This program allowed the production of fairly easily manageable data. It was possible, for example, to determine which words clustered with the word 'culture', and it allowed numerical comparisons between the different texts.

\section{Findings: At Least Two Concepts of Culture}

A few observations were very easy to make from the data produced with the concordance program. First, the searched words were anything but evenly distributed in the articles and dissertations. In some texts they were used extremely often, in others scarcely at all. Second, this unevenness was not arbitrary, but depended strongly on the subject of the article or dissertation: for example, narratives, oral history, or folktales did not seem to necessitate the use of the concept of culture-or at least not the words I was searching for-whereas articles dealing with subjects such as heritage, cultural identity, or ethnic minorities were sometimes filled with these words.

Because of the length of the texts, the third observation was easier to make from the dissertations than from the articles: the searched words were not always used evenly even within one text. In the graphs produced with the concordance program, a black vertical line marks the searched words.
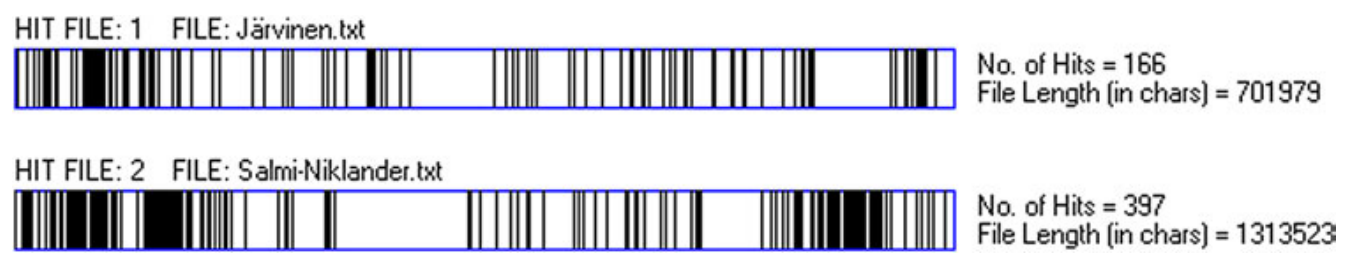

Figure 1. The searched words in two doctoral dissertations.

These graphs (Figure 1) represent two dissertations (Järvinen 2004; Salmi-Niklander 2004) in which the unevenness is very clear. The searched words appear at the beginning, when the authors describe their theoretical starting points and methods, and 
give an initial outline of the subject of their work, as well as at the end, when they discuss their findings. The long blank breaks represent chapters in which they analyse their data in detail. The same phenomenon was also apparent in many of the other texts: the writers used the searched words more in the theoretical discussion and in the outlining or contextualization of the research subject than when concentrating on the details of their data.

As already mentioned, it was indeed possible to recognize at least two concepts of culture used in the studied texts. Many of the idioms in both the Finnish and English texts contained one of the searched words. In other cases it was impossible to distinguish a specific concept of culture based on these data alone. Nevertheless, in those texts containing a greater than average number of the searched words, a clearly distinguishable, if not definable, concept of culture was used. Also, in a very different and more restricted group of texts, using the searched words (although much less than in the previous case) one could identify a clearly different concept of culture. Intermediate forms existed, as we shall see, but the two concepts were clearly distinguishable.

One concept (the one I was originally looking for) was, not surprisingly, prominently used when discussing identity politics, ethnic minorities, the revival of local identities and traditions, and cultural heritage. The clusters and collocates confirm this. The studied words appeared repeatedly in expressions such as 'cultural heritage', 'cultural landscape', 'Sámi culture', 'cultural representations', 'culturebuilding', 'ethnic and cultural', 'multicultural contexts', 'cultural contacts', and 'indigenous cultures'. The concept was found in both the English and Finnish texts when the authors discussed minorities such as the Sámi, the Seto, or the Ugric peoples of Siberia, especially when the research was based at least partly on recent fieldwork, and not only on archival materials. In some cases, the way in which the searched words were used gave the impression that today only minorities have this kind of 'culture'; national cultures of nation-states were mentioned only when contrasted with the minority cultures, as in the expression 'mainstream Estonian culture' (Kuutma 2006). As we shall see, this concept proved to be a problematic one, and it was impossible to derive an unambiguous definition of it. Nevertheless, there were good reasons to treat it as one concept, not several. It was possible to distinguish at least implicit disagreements about the meaning of 'culture' between the different researchers who used the concept, and these disagreements could not be resolved by differentiating culture1 from culture2.

The second concept of culture appeared in some of the articles and most of the dissertations based on archival work, but was rare (although not non-existent) in texts based on fieldwork. The texts in which this concept was used contained fewer of the studied words than texts using the first concept. This concept was much more uniform than the first, and differed from it clearly. It was often used to coin such expressions as käsikirjoituskulttuuri (manuscript culture) or 'song culture' consisting of a kind term and the word 'culture'. I will venture to offer a loose definition of it (something that was not attempted in any of the texts).

Some intermediate forms occurred between the two concepts. These could be found in expressions such as lumilautailukulttuuri (snowboarding culture) or 'research culture'; that is, expressions that were coined similarly to most of the expressions implying the 
second concept, but without referring to any distinguishable kind. In addition, they were often used in research based on fieldwork, or at least research that in some way dealt with living people, not just archive material.

The main difference between the two concepts is that the first mentioned concept is mainly used when discussing what Robert K. Merton (1968) called 'grand theories', and the second is used mainly when formulating 'theories of the middle range' or 'substantial theories'. Merton distinguished three different theoretical levels in sociological research: grand theories; working hypotheses about individual research subjects (which, however, can be formulated in theoretical language); and between the two, 'theories of the middle range'. Grand theories are 'all-inclusive systematic efforts to develop a unified theory that will explain all the observed uniformities of social behaviour, social organization and social change' (Merton 1968, 39). They can also be understood as conceptual frameworks used to enrich the natural language. They make it possible to conceptualize the research subject in a more exact and nuanced way than the natural language allows, but within them it is possible to make divergent claims about the subject. Such theories can either be fruitfully applied to the phenomena of interest, or cannot, but often they involve large-scale ontological claims that make it difficult or even impossible to prove them right or wrong. Theories of the middle range, or substantial theories, make claims about sets of phenomena, their properties, and interactions within them. Such theories are either correct or mistaken (Merton 1968; Hedström and Ylikoski 2010).

In other words, even though both of the concepts of culture are used in theoretical discussions rather than when concentrating on the details of data, the theoretical discussions where they are used differ from each other. The second, definable concept is used in the formulation of certain substantial theories, whereas the more problematic concept is connected to competing grand theories. As noted, the tensions between grand theories are related to a gradual but important change in the research subject of much cultural research.

\section{Kind-Constructing Culture}

Let us start with the second concept, as it is easier to grasp than the first. This is a beautiful example of how an ordinary concept can be taken into use in research by choosing to focus on one of the ways in which the corresponding word is used in our everyday speech. It is used in expressions such as 'poetic culture', 'song culture', or 'manuscript culture', which consist of a kind term, such as 'manuscript' or 'song', and the word 'culture' or 'kulttuuri'. The concept is used more often in texts written in Finnish than in those written in English. It might be, given the limited number of studied texts, that this is just a coincidence, but it is also possible that for some reason it is easier to coin such expressions in Finnish than in English, or that there was at the time an ongoing discussion, conducted mainly in Finnish, in which the concept was used.

As mentioned above, I have tried to give a loose definition of this concept of culture: 'culture' in these cases is a historically and locally limited, complex social mechanism that creates and sustains a homeostatic property cluster, such as a distinctive kind of 
manuscript or song. To understand the definition we need to understand Richard Boyd's (1991, 1999) analysis of 'natural kinds' as 'homeostatic property clusters'.

Natural kinds, as opposed to ad-hoc classifications or conventional ones (such as 'the things on my desk' or 'oriental spices'), make inductive inferences possible. One can study just a small sample and generalize the findings across the whole kind. The elements (e.g. iron) and biological species, such as Felis catus, are paradigmatic examples of natural kinds: they share a large number of causally unrelated properties (a tail does not cause purring, and vice versa), and it is possible to make new discoveries about the whole kind by studying small samples of it. According to the traditional view, the natural sciences try to find natural kinds and trace their law-like relations with each other. Many theories of natural kinds would treat them as ahistorical, uniform, clearly defined, and governed by the laws of nature. This, however, has proved problematic, as only some of the paradigmatic examples fit this picture. Iron indeed is such a uniform and ahistorical natural kind governed by natural laws. Its properties do not change with time (iron does not evolve), and it is possible to study a very small sample of iron and generalize the findings reliably across the whole kind. However, biological species are historical, they are not entirely uniform nor do they have clear boundaries, and it is difficult to find natural laws that would directly govern them.

Boyd $(1991,1999)$ responded to this problem with his analysis of natural kinds as homeostatic property clusters. A homeostatic property cluster is a set of properties that cluster reliably (i.e. they maintain homeostasis; the properties of the cluster remain relatively stable and constant), and thus form a kind. This happens because of some internal or external mechanism; not, for example, because of some essential factor that would unite the research subject and from which these properties would necessarily follow. Biological species are a good example of this: a continuous gene flow through breeding between the different parts of a population ensures the clustering of certain properties within it. So, even if no specific animal belonging to the population has all of these properties, it is possible to say that the kind in question-the species-has the properties. For example, there are entirely black cats, there are tortoiseshell cats, and there are tabby cats, but no single cat can be all three at the same time. Nevertheless, all three coat patterns are properties found in the species F. catus. Homeostatic property clusters can also have fuzzy boundaries, like in cases where it is not possible to distinguish the exact borderline between two close biological species. Thus, a kind can be historical and heterogeneous, and have vague boundaries, and still not be a mere conventional classification, but a kind that the researcher finds in the world. The mechanism that causes the clustering of properties also makes inductive reasoning reliable. A researcher can, for example, study the properties of a limited number of animals belonging to a species, and make the inductive assumption that the findings apply to the whole species.

The phenomena the humanities study are obviously not only historical, but also social. Kinds in the humanities are less stable than in chemistry or even biology. Ian Hacking $(1995,1999)$ has introduced the thesis of the 'looping effect of human kinds'. When people are classified in a certain way, they sometimes change their behaviour as a response to the classification, and as a result the description of the kind has to be changed. That is, when members of a certain kind no longer behave as they did before, the distinct properties of the kind in question have changed. This makes human kinds unstable, and seems to 
distinguish them from kinds in the natural sciences. Boyd's analysis, however, makes the naturalness of a kind a relative feature. At one end of the spectrum are the elements, and at the other end are purely ad-hoc classifications (such as 'the things on my desk'), but there is a great deal in between. Ron Mallon (2003) has used the idea of homeostatic property clusters when discussing social roles. As he notes, people's reactions to the ways in which they are classified can stabilize as well as destabilize human kinds. Institutional social roles in particular-Mallon mentions US Senators and licensed bass fishermen $(2003,322)$-can be very stable precisely because people hold on to them and do not wish them to change. He points out the role of customs in producing property clusters, from which fairly reliable inductive inferences can be made. Let us call kinds like this 'quasi-natural'. They are indeed less stable than most natural kinds that the natural sciences study, but they are not mere conventional classifications, and it is possible to make inductive inferences about them. They are property clusters, and they are homeostatic enough for the researchers' needs. Traditions and peoples' own conceptualizations can play a role in the mechanisms that hold these property clusters together (see also Kuorikoski and Pöyhönen 2012; Pöyhönen 2013).

The researchers who use the second concept of culture-let us call it the 'kindconstructing culture'-in the studied texts base their work typically on archived materials such as texts, photographs, or recordings collected by someone else, usually by several people, and over a long period of time. This does not mean that the archive provides researchers with ready data. Archive collections have typically been collected and organized by earlier researchers whose theoretical background differed significantly from that of contemporary researchers, even if they represented the same academic discipline. For example, old archived materials are often seen by contemporary researchers as 'decontextualized artefacts', 'severed from their communicative, cultural and textualized surroundings' (Tarkka 2005, 524). The classifications used in the archive might not serve a contemporary researcher's purposes; and even when they do, older collectors have often omitted elements that would be valuable from the point of view of a researcher trying to answer research questions very different from those older collectors had in mind. Accordingly, contemporary researchers must carefully choose the material they use in their study. This choosing process is guided by theoretical assumptions, and it necessarily involves interpretation. Thus the process of finding the archive material that can shed light on the research question the researcher has in mind can be understood as resembling the process of 'producing data'. ${ }^{4}$

According to James Bogen and James Woodward (1988), scientific theories are not about observations, or what is observed, or data. Instead, data serve as evidence for the existence of phenomena-for example, of a quasi-natural kind. Data, once they have been produced, can be observed, whereas phenomena usually cannot. Yet data are fairly unpredictable. No theory can predict or systematically explain the exact data that will result from a specific experiment:

Examples of data include bubble chamber photographs, patterns of discharge in electronic particle detectors, and records of reaction times and error rates in various psychological experiments. Examples of phenomena, for which the above data might provide evidence, include weak neutral currents, the decay of the proton, and chunking and recency effects in human memory. (Bogen and Woodward 1988, 306) 
Similarly, no theory about Kalevala-metre poetry ${ }^{5}$ will make understandable all of the unique features of the exact data; that is, the poems a researcher gathers from the archives. This is because theories are about phenomena. A theory concerning Kalevalametre poetry would be about phenomena that can be determined by studying the data: for example, the phenomenon that many or most of the poems collected from a specific area share some specific features.

The data produced serve as evidence for the existence of the phenomena the researcher wishes to study. Researchers who use the kind-constructing culture concept are typically interested in two kinds of phenomena: first, the kind in question (a kind of poem, a kind of manuscript, or a kind of song); and second, the culture that produces and sustains the kind, and the ways in which it functions. For example, the existence of a distinctive kind of manuscript in Finland at the beginning of the twentieth century (Salmi-Niklander 2004) must be demonstrated by referring to the data before any substantial theories about the kind in question can be stated and defended. This could be done by showing a distinguishable cluster of properties that systematically recurs in the data. In other cases, when the existence of a quasi-natural kind is generally accepted-for example, the existence of Kalevala-metre poetry as a distinguishable kind (Tarkka 2005) does not need to be proved-the data serve as evidence when the researcher makes further claims about the kind, like describing the specific mechanism that produced it.

These kinds are not seen as conventional classifications made by the researcher, but as something existing in the world independently, and it is possible to make fairly reliable inductive inferences about them. They usually share several properties that are not obviously connected, and in appropriate conditions the kind can in some cases remain, if not the same, at least clearly continuous for a fairly long period of time. They are often distinguishable, but there are also borderline cases; such as manuscripts that resemble but also differ somewhat from the kind of manuscripts Kirsti Salmi-Niklander (2004) studies. In other words, these are quasi-natural kinds that can be understood as homeostatic property clusters, in which a set of properties cluster reliably (maintain homeostasis), and thus form a kind due to a social mechanism that sustains the clustering. Sometimes researchers discuss whole homeostatic property clusters, but often they only concentrate on parts of them. A researcher might study the Kalevalametre poetry of a fairly small area (Tarkka 2005) without claiming that it would differ radically from the poems of the neighbouring areas. Nevertheless, even in these cases the kinds are not understood as conventional classifications; the researcher simply concentrates on one part of a larger homeostatic cluster.

The kinds mentioned above are genres, or closely related to genres. The manuscripts Salmi-Niklander discusses form a local, relatively short-lived genre, and the Kalevalametre poetry Tarkka studies consists of several subgenres-'mythical-historical and local-historical epic poems, incantations and spells, lyrical poems and aphorisms, singers' opening formulae, wedding songs, bear ritual songs, lullabies and children's rhymes, yoiks and various minor genres' (Tarkka 2005, 522). Genres are the subject of important theoretical work in folkloristics. The possibility of making inductive inferences about local genres has often been connected to the notion of tradition: the relative stability of local forms makes the inferences and generalizations possible, and the stability is seen as resulting from tradition. Traditions are recognizable; and 
although variation is possible, it is limited, as excess variation would lead to difficulties in recognition and understanding (Foley 1995; Frog 2013, 106). Most folklorists today emphasize the instability of genres and the importance of invention as well as tradition, but many local genres are nevertheless seen as something stable enough for inductive inferences to be possible (Ben-Amos 1976; Shuman and Hasan-Rokem 2012). In the studied texts, the notion of culture, in addition to tradition, was applied when exploring the stability of the studied kinds.

If a local form, such as Kalevala-metre poetry, is understood as a homeostatic property cluster, the kind-constructing culture is the complex social mechanism that causes the clustering and thus sustains the kind. As an example, in her dissertation on Kalevalametre poetry in Vuokkiniemi, Tarkka describes the poetic culture as a 'praxis and a set of themes' $(2005,522)$, and as a 'common poetic language' $(2005,523)$ that had an important role in the community:

The meaning or function of the poetic culture can be assessed on this very conceptual level: Kalevalametre poetry provided a language and a structure for organizing cultural knowledge in a synthesizing manner. The present reached for the mythical past, the individual to the collectivity, and the songs sung by the ego embraced the words of the others. The power of words was based on this very depth of communal and traditional language.

Singers and their audiences alike used the poetic culture in constructing a local and historical sense of belonging. In heightened performances the singers discussed topical issues and values while experiencing communality enhanced by singing, arguing, dancing and alcohol. While performed, tradition was construed as a social fact. Performing tradition was a deed which expressed membership in the old speech community, created continuity and reinforced cultural identity. The songs were 'the old songs of Karelia', our songs. This need not imply a homogeneous and harmonious local culture. On the contrary, poetry highlighted dilemmas and presented various, even conflicting points of view. In bakhtinian terms, Kalevala-metre poetry was a dialogical discourse. (Tarkka 2005, 529)

I read Tarkka here as proposing a substantial theory about the poetic culture and the poems. She describes a mechanism that could sustain the kind we know existed, and gives a plausible account of the reasons why such a mechanism might have been a relatively strong one, and could have sustained the homeostatic property cluster for a fairly long period of time. As we can see, this mechanism relies partly on people's awareness of both the uniqueness of their poems, and of the mechanism-the praxis and the shared language-that kept the poems flowing.

As mentioned earlier, there are intermediate forms between the kind-constructing culture and the other concept of culture I found in my sample of texts, in such expressions as 'archiving culture' (Mahlamäki 2001) or 'lumilautailukulttuuri' (Hänninen 2007). The form of the expressions closely resembles the form we see in 'song culture' or 'manuscript culture', but they do not include a kind term. One can mention one song or one manuscript, as one can talk about one F. catus or one sample of iron, but it makes less sense to talk about one snowboarding or one sample of snowboarding. Fittingly, even though talk about snowboarding culture clearly indicates the idea of local, regularly clustering properties that differ from what is typical in the surroundings, and perhaps also of some social mechanism that sustains the clustering, it is less clear where the properties in question are to be found. There is no clear kind, which brings us closer to the other concept of culture. 


\section{Bone-of-Contention Culture}

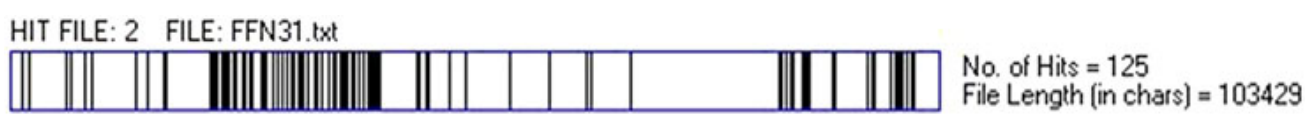

Figure 2. The searched words in a journal issue.

As we see from Figure 2 representing an entire issue of Folklore Fellows' Network bulletin (no. 3, December 2006), the searched words are used in some articles much more than in others. The dense part on the left-hand side of the graph marks Kristin Kuutma's article 'Changing Codified Symbols of Identity', in which one of every forty-eight words is 'culture' or 'cultural'. Certain other articles in other journal issues stood out in a similar way, by using the searched words extremely often and by sharing certain other features with Kuutma's article. Here I try to explain why the searched words are used so abundantly in these articles. Most of them concentrate on themes such as identity politics, ethnic minorities, the revival of local identities and traditions, and cultural heritage (O'Giollain 2005; Kupiainen 2009; Lukin 2005; Mathisen 2007; Virtanen 2007). There seems to be one concept of culture in use, yet one definition is not possible. This, I believe, is because the concept is understood differently in different theoretical frameworks. There are different theories precisely about this concept of culture-unlike the kind-constructing culture concept, which can be used when formulating different theories. Moreover, these theories about culture tend to be in the sphere of 'grand' theories, whereas the kind-constructing culture concept is used when formulating 'substantial' theories.

For reasons that will soon become clear, I would like to call this concept the bone-ofcontention culture concept. For a better grasp of it, I suggest the use of ideas developed in both the philosophy of science and conceptual history. We also need to look at the environment where it is currently in use.

This concept of culture has been at the centre of many debates in anthropology and its neighbouring disciplines, and in the last decades of the twentieth century the whole concept was seriously questioned. The idea of different cultures as the subject of research had become quite problematic. Researchers were no longer collecting the remains of disappearing tribal cultures or describing them from somewhere above. Also, the idea of somehow authentic and unspoiled cultures had been ridiculed often enough. The objectivity of the earlier cultural sciences had been questioned, and many old studies were now seen as scarcely veiled colonialism (Kuper 1999; Risjord 2007). But while researchers were dismissing such ideas as authenticity, clear-cut national cultures, different sorts of essentialisms, illusions of objective cultural science, and at the same time problematizing the concept of culture, they also witnessed its practical political force. People all around the world had appropriated the word and were using it as a very efficient tool in their identity politics-precisely because of its essentializing power (Clifford 1988; Wagner 1975). Adam Kuper mentions a migrant labourer who returned to his New Guinea people, the Baruya, and proclaimed, 'We must find strength in our customs; we must base ourselves on what the Whites call culture' (Kuper 1999, 2). Marshall Sahlins has noted the irony in these two contemporary processes: 'So pretty soon everyone will have a culture; only the anthropologists will doubt it' (Sahlins 1999, 402). 
During the last few decades folklorists have begun studying the kind of phenomena some early folklorists were involved in: the defining, revival, and strengthening of local identities, even nation-building. Only this time folklorists are studying the processes rather than participating in them (Wilson 1976; Anttonen 2005, 2012). In the abovementioned article, Kuutma focuses on the cultural movements of the Seto and the Sámi. In the other articles where the bone-of-contention culture concept is used, the focus is also mainly on minorities in Northern Europe and Siberia. Similar movements can, however, be observed all around the world. The activists behind these movements use the concept of culture, which for them has political, and sometimes also economic, value. Minority cultures are important not only personally and politically for the people who relate to them, but also for the local economy, as cultural specialities, heritage, and festivals draw tourists (Siikala 2000; Olsen 2004).

The line between local cultural activists and academic researchers has been blurred. In addition to more or less political cultural movements, the last few decades have also witnessed the birth of academic research that actively participates in these movements. Folklorists who study the contemporary Sámi cultural movement have fellow researchers who represent indigenous studies, and who aim at advancing the indigenous identity, self-determination of the indigenous peoples, mental decolonization, and even nation-building (Kuokkanen 2000; Stordahl 2008; Tuhiwai Smith 1999). The concept of culture is used profusely in this kind of politically active research, and sometimes in ways that sound like the reification of culture, or at least like the kinds of 'generalizations about the culture as a whole' (Risjord 2007, 416) that have often been questioned within anthropology and the neighbouring disciplines.

None of the articles I studied was extremely political, but it is clear that the concept of culture used by researchers should not be separated from the concept of culture used by the people they study if the aim is to understand what is being done with the concept. The theoretical stances related to 'culture' that some researchers defend seem similar to ones advanced by activists (Koskinen 2011). This concept of culture is politically loaded, and to analyse it I will add to Merton's distinction between substantial theories and grand theories the notion of 'contested concepts' developed in conceptual history by Reinhart Koselleck.

According to Koselleck $(1985,1996)$, certain political concepts such as 'revolution' or 'democracy' sometimes attain the status of bones of contention in political disputes. It becomes increasingly difficult to define them, as the different, competing definitions are an integral part of the political disagreement. They 'combine manifold experiences and expectations in such a way that they become indispensable to any formulation of the most urgent issues of a given time' (Koselleck 1996, 64). It also seems that in the context of academic research, certain words can sometimes become 'indispensable to any formulation' of an urgent theoretical issue, while at the same time it becomes more difficult to define the concept the word expresses. These words are necessary because the debates cannot be conducted without them, and simultaneously the concepts are necessarily ambiguous and contested. The different sides in the debates express their differences by using the relevant words in different ways. ${ }^{6}$ I would like to suggest that the abundant use of the searched words in some of the studied texts can at least partially be explained: the words 'culture' and 'cultural' and their Finnish equivalents are used 
abundantly because there are notable disagreements concerning the bone-of-contention culture concept.

These disagreements involving the bone-of-contention culture concept are typically on the level of Merton's grand theories. Merton characterizes sociological grand theories as 'all-inclusive systematic efforts to develop a unified theory that will explain all the observed uniformities of social behaviour, social organization and social change' and states that they are too abstract to be 'incorporated in propositions that permit empirical testing' $(1968,39)$. Hence grand theories, such as Marxist theory, can be understood either as very large-scale theories making ontological claims, or as conceptual frameworks that either can or cannot be fruitfully applied to the phenomena of interest. Either way we look at the grand theories in question here, the bone-ofcontention culture concept appears to be a contested one.

As an example of a tension between different grand theories about culture, let us focus for a moment on two articles: Kristin Kuutma's 'Changing Codified Symbols of Identity' (2006) and Anna-Leena Siikala's 'Mythic Discourses: Questions of Finno-Ugric Studies of Myth' (2008). Kuutma discusses the ongoing negotiations and processes of constructing cultural identities:

The construction of tradition, or its invention, is essentially a process of formalisation and ritualisation -it is generally a reaction to an alteration of circumstance, and occurs often in a situation when the swift social transition weakens or destroys previously established social patterns (Hobsbawm and Ranger 1983). And it is geared towards creating a unified cultural expression, with an eventual goal of establishing representative cultural symbols. (Kuutma 2006, 8)

Siikala studies myths that have been transmitted from one generation to another for centuries or even millennia:

Fundamental mythic images are so widespread that they have been considered universal manifestations of the workings of the psyche. Eternal and universal mythic images are, however, culturally determined and handed down within a culture. Their meanings emerge from a process of interpretation in which the symbolism of the cosmos, and the nature of the otherworld and human kind, is filtered through an individual culture, the reality subsisting within the consciousness of the community and of the person, and its flip-side, a second reality. Mythic images are based on the logic of the impossible. It is precisely in their contradiction that they are able to form world images which have proven comprehensive and thus influential. They are both ancient and continually reborn. (Siikala 2008, 6)

As can be seen from these quotes, the theoretical orientations the authors have adopted in these articles lead them to understand 'culture' in two quite different ways. Kuutma mentions 'establishing cultural symbols' and 'creating a unified cultural expression', and even 'culture building' $(2006,10)$. In other words, she sees culture as being re-organized and negotiated all the time, and as tightly intertwined with social and political issues. It can go through significant changes in short periods of time, and can even emerge relatively quickly out of something very different. Siikala, on the other hand, writes about cultures as living much longer than individuals and shaping the way in which people born into them conceive the world. These are two quite distinct ways of understanding culture, yet both authors undoubtedly understand each other, and actually at times use the bone-of-contention culture concept in a way that contradicts their general orientation. Siikala agrees that research into myths is important "when 
constructing cultural identity for small peoples' $(2008,5)$, and Kuutma states that on 'ecological, economic, regional, linguistic and social grounds the Sámi may be divided into a number of component cultures with their own history, identity and symbol system' $(2006,10)$.

In their articles both Siikala and Kuutma often use the studied words 'culture' and 'cultural'. I suggest that one of the things they are doing with the bone-of-contention culture concept is taking part in a specific discussion concerning the definition of culture: should a culture be understood as actively organized or even constructed by people and continuously changing, or as something that survives for a long time, changes slowly, and shapes the ways in which people think? Moreover, should culture be seen as an inherently modern way of organizing identities, or as something that has shaped human experience and thought always and everywhere? These questions have gained importance as the concept has been taken into use both in political movements and in overtly political research connected to these movements. Different answers to the questions indicate a variety of competing grand theories about culture, which are expressed both explicitly and in the different ways the bone-of-contention culture concept is used. Siikala has participated actively in the theoretical debates surrounding the concept of culture. Together with Jukka Siikala she defends both the use of the concept as a theoretical tool, and the idea of culture as a system that both creates unity and is based on differencesculture as 'the ordering order determining in a systematic way what is claimed, contested and the ways contestation is accomplished' (Siikala and Siikala 2005, 281).

The debates in which the concept of culture is a bone of contention go further than questions about unity, continuity, construction, and change. Anthropologists, both social and cultural, have questioned the whole concept as a tool suitable for a researcher's purposes. Some ideas about the nature of language and concepts have led some cultural anthropologists to claim that if all our concepts are meaningful only within a culture, then also the concept of culture used in this claim is just a Western notion that might not apply in any meaningful way to non-Western people (Wagner 1975; Kuper 1999). As an analytical tool, this concept of culture might be, at best, only a practical way to lump together and objectify heterogeneous phenomena. For example, social anthropologist Marilyn Strathern talks of theoretical constructs, such as culture or society, as something we can find in a researcher's tool kit and that can be projected onto the data if needed, but that we should not expect to exist in the world as autonomous phenomena (Strathern 2004, 38).

In other words, researchers have noted that the bone-of-contention culture concept is part of a conceptual framework used in cultural research, and that this framework is not necessarily the only possible one. It might be applicable and useful, but it is a mistake to assume that it is like the concepts in 'substantial' theories. The fact that the concept can be projected onto the world does not mean that it would correspond to an independent phenomenon. And even if it was useful, there might be other fruitful ways to conceptualize the studied phenomena. Also, it is not at all clear whether the bone-ofcontention culture concept is a good tool for researchers today. Earlier, it was used as if cultures were autonomous phenomena; latterly, this has been strongly called into question.

However, as already noted, peoples whom cultural researchers have classified using the bone-of-contention culture concept have now adopted it themselves. The adoption 
and use of the concept have had an impact on how people understand their communities and identities, so it is not surprising that a significant number of researchers, Siikala amongst them, defend the use of the bone-of-contention culture concept in research (Sahlins 1999; Siikala and Siikala 2005). James Clifford has noted that 'culture' for him 'is a deeply compromised idea I cannot yet do without' $(1988,88)$. The reason he gives seems to be at least partly moral and political: 'culture' is the only word he knows with which he can talk about the different peoples of the world as different from each other. It has moral force. Also, as the concept has been adopted by many of the people that cultural researchers study, and as they often see their cultures as a significant part of their lives, should not the researchers take this seriously? The opposite view, of course, continues to have its advocates. In a discussion on a case study from the Polish Carpathians, one of the numerous small Eastern European groups that after the collapse of the Soviet Union have started to seek recognition, Hann comments on the research conducted in the area, and the embarrassing overlap between the anthropological usages and the nationalists' usages' $(2002,273)$ of the concept of culture.

When this critique of the whole bone-of-contention culture concept is taken into account, Siikala and Kuutma appear to represent the same side in the debate. They obviously both find the concept useful, even necessary, in their work. It is fully possible that the authors of some of the studied articles who did not use the searched words represented the opposite view.

\section{Conclusions}

The focus in this paper has been on two concepts of culture: one that mostly lives peacefully in its own niche of archival work; and the other which is not only spread out over several disciplines, but which is also used abundantly by the people these disciplines study.

The first concept I have called the kind-constructing culture concept and analysed as a way of naming independent phenomena that researchers find when studying their data: historically and locally limited complex social mechanisms that construct and support kinds-such as the manuscript culture in Finland in the early twentieth century. The kinds in question can be understood as homeostatic property clusters. That is, several otherwise non-related properties cluster fairly reliably because of the culture that holds the cluster together, and it is possible to make inductive inferences about the kind.

The second concept I have called the bone-of-contention culture concept, and have analysed it using the idea of 'contested concepts'. A given concept is necessary because the related theoretical debates cannot be conducted without using it, and at the same time it is necessarily ambiguous and contested. The opposing sides in the debates express their differences through different ways of using the relevant words. In addition, the disagreements about culture may be divided into two categories: the competing grand theories about culture; and critical discussion about the acceptability of the very concept as part of a conceptual framework suitable for researchers' use. In the studied texts these debates showed in the ways in which the bone-of-contention culture concept was used, but the debates were rarely explicitly discussed.

There is a clear difference between the two concepts. The critique aimed at the bone-of-contention culture concept as part of a researcher's conceptual framework has 
very little, if anything, to do with the kind-constructing culture concept. Few researchers would doubt the existence of such phenomena as the manuscript culture in Finland at the beginning of the twentieth century. Some might object to the use of the word 'culture', but the concept is unproblematic enough, since the claim that the phenomenon-the social mechanism that produces a homeostatic property cluster-has existed is a substantial claim that can be supported by referring to data, and that could in principle also be proved incorrect. In other words, the kind-constructing culture concept is used when formulating substantial theories, whereas the bone-of-contention culture concept is used in debates that move in the sphere of grand theories.

The bone-of-contention culture concept is a notoriously debated one. It has often been entangled in theoretical disputes in anthropology and its neighbouring fields, and at present it is once again in the centre of a debate. The people whose cultures used to be studied by cultural researchers have taken the concept into political use. In some cases, people belonging to groups that used to be given the role of research subjects or informants have started conducting research on their own cultures. That is, these people are not only 'returning the gaze', but participating in the creation of new forms of research, even of new disciplines, and thus reshaping the field of cultural research. The research subjects of cultural research have changed, which has an effect on the development of grand theories in many disciplines falling under the umbrella of cultural research.

The last time any concept of culture was strongly debated in the context of Finnish folkloristics was when it was in the centre of a dispute concerning popular culture (Krogerus 2014, 751-64). However, folkloristics, especially in countries like Finland, is in an interesting position regarding the above-mentioned change, because a century ago the discipline took an active part in the building and defining of national identities-a process that resembles the contemporary political projects of many minorities and ethnic groups. Since then folkloristics has gone through a post-nationalist self-critique comparable with the post-colonialist self-critique in anthropology (see, for example, Anttonen 2005, 2012; Wilson 1976). As noted, politically motivated research that forms a part of the contemporary cultural movements resorts at times to problematic theoretical claims and research practices, such as the reification of culture. Some of the critique presented against earlier nationalist folkloristics is also relevant in the context of contemporary overtly political cultural research. Folklorists participate actively in the discussion surrounding these cultural and political movements. However, it could be useful if some theoretical viewpoints of potential value in the development of the related new forms of cultural research-for instance, perspectives on the bone-of-contention culture concept-were more openly discussed.

\section{Funding}

This work was supported by the Kone Foundation.

\section{Notes}

1 I am grateful to the authors of the doctoral dissertations and to the Finnish Literature Society for their important help in accessing the dissertations in electronic form. For inspiring discussions, I would like to thank everyone who attended the Suomen kansantietouden tutkijain seura symposium in 2010, especially Seppo Knuuttila for his useful advice and Outi Lehtipuro for her highly interesting comments on the 
discussions concerning the concept of culture in folkloristics in the 1960s and 1970s. Earlier versions of this paper were presented at Concepta Research Training Seminars in Madrid and Oslo. Finally, I owe many thanks to Frog, Petja Kauppi, Tomi Kokkonen, Samuli Pöyhönen, and two anonymous referees for their valuable comments.

2 'Kind' is a term used to refer to groupings used by researchers. Iron, F. catus, science fiction, attentiondeficit hyperactivity disorder, and lament are all kinds.

3 At the time of writing (summer 2014) the program can be downloaded from Lawrence Anthony's homepage: http://www.antlab.sci.waseda.ac.jp/antconc_index.html

4 I am indebted to Päivi Seppälä and Petri Ylikoski for their observations on the dissimilarities between producing data in the experimental sciences and finding 'traces' of the past in the historical sciences. In the latter, researchers cannot produce entirely new data.

5 Kalevala-metre is a loose trochaic tetrameter typical in Balto-Fennic oral poetry.

6 Douglas C. Dow (2008) has studied an interesting example of the contestability of concepts used in research. In the early twentieth century, legal personhood was considered one of the main theoretical problems in jurisprudence, and was treated with due interest in the discipline's literature. By midcentury the debate had ended, but not because an agreement had been reached. No consensus emerged; other theoretical issues just replaced the older one. What is interesting in Dow's story is that when the debate faded, the term 'legal person' started to be more and more difficult to find in juridical discourse. It still had a meaning; as a term denoting a being with a legal status it was always understandable, but its usage declined substantially (Dow 2008, 8-9). It seems that the term 'legal person' was necessary primarily in the debates concerning legal personhood.

\section{PhD Dissertations Analysed}

All Finnish dissertations are published. Where not otherwise indicated, the following were published in Helsinki by the Finnish Literature Society.

Aarnipuu, Petja. Turun linna kerrottuna ja kertovana tilana [The Turku Castle: cultural heritage as narrative space]. 2008.

Anttila, Anna. Leikin asia: näkökulmia varhaisnuorten romanttiseen seurustelukulttuuriin [Perspectives on the romantic dating culture of preadolescents]. Helsinki: Anna Anttila, 2009.

Järvinen, Irma-Riitta. Karjalan pyhät kertomukset: tutkimus livvinkielisen alueen legendaperinteestä ja kansanuskon muutoksista [Karelian sacred narratives: a study of Orthodox religious legends and changes in folk belief in the Livvian-speaking area of Karelia]. 2004.

Latvala, Pauliina. Katse menneisyyteen: folkloristinen tutkimus suvun muistitiedosta [A glimpse into the past: a folkloristic investigation into the oral history of the family]. 2005.

Piispanen, Sirkku. Kansanomainen moraali: tutkimus savolaisista ja pohjalaisista uskomustarinoista [Folk morals: research on belief legends from Savo and Ostrobothnia]. Mikkeli: Sirkku Piispanen, 2009.

Salmi-Niklander, Kirsti. Itsekasvatusta ja kapinaa: tutkimus Karkkilan työläisnuorten kirjoittavasta keskusteluyhteisöstä 1910- ja 1920-luvuilla [Self-education and rebellion: a conversational community of working class youth in Karkkila during the 1910s and 1920s]. 2004.

Tarkka, Lotte. Rajarahvaan laulu: tutkimus Vuokkiniemen Kalevalamittaisesta runokulttuurista 1821-1921 [Songs of the border people: Kalevala-metre poetry in Vuokkiniemi Parish 1821-1921]. 2005.

Timonen, Senni. Minä, tila, tunne: näkökulmia Kalevalamittaiseen lyriikkaan [Self, space, emotion: aspects of Kalevala-metre folk lyric]. 2004. 


\section{References Cited}

Anttonen, Pertti. Tradition through Modernity: Postmodernism and the Nation-State in Folklore Scholarship. Helsinki: Finnish Literature Society, 2005.

'Oral Traditions and the Making of the Finnish Nation'. In Folklore and Nationalism in Europe during the Long Nineteenth Century, edited by Timothy Baycroft and David Hopkin, 325-50. Leiden and Boston: Brill, 2012.

Ben-Amos, Dan. 'Introduction'. Folklore Genres, edited by Dan Ben-Amos, ix-xlv. Austin: University of Texas Press, 1976.

Bogen, James, and James Woodward. 'Saving the Phenomena'. Philosophical Review 97 (1988): 303-52.

Boyd, Richard. 'Realism, Anti-Foundationalism, and the Enthusiasm for Natural Kinds'. Philosophical Studies 61 (1991): $127-48$.

—. 'Homeostasis, Species, and Higher Taxa'. In Species: New Interdisciplinary Essays, edited by Robert A. Wilson, 141-85. Cambridge, MA: MIT Press, 1999.

Clifford, James. The Predicament of Culture: Twentieth-Century Ethnography, Literature, and Art. Cambridge, MA: Harvard University Press, 1988.

Dow, Douglas C. 'Decline as a Form of Conceptual Change: Some Considerations on the Loss of the Legal Person'. Contributions to the History of Concepts 4, no. 1 (2008): 1-26.

Foley, John Miles. The Singer of Tales in Performance. Bloomington: Indiana University Press, 1995.

Frog. 'The Parallax Approach: Situating Traditions in Long-Term Perspective'. In Approaching Methodology, edited by Frog, Pauliina Latvala, and with Helen F. Leslie. 2nd rev. ed., 99-129. Annales Academiae Scientiarum Fennicae Humaniora 368. Helsinki: Academia Scientiarum Fennica, 2013.

Hacking, Ian. 'The Looping Effect of Human Kinds'. In Causal Cognition: An Interdisciplinary Approach, edited by Dan Sperber, David Premack, and Ann James Premack, 351-83. Oxford: Oxford University Press, 1995.

—. The Social Construction of What? Cambridge, MA: Harvard University Press, 1999.

Hann, C. M. 'All Kulturvölker Now?' In Anthropology beyond Culture, edited by Richard G. Fox and Barbara J. King, 259-76. Oxford: Berg, 2002.

Hänninen, Riitta. 'Vapauden merkitys lumilautailukulttuurissa' [The meaning of freedom in snowboarding culture]. Elore 14, no. 2 (2007). http://www.elore.fi/arkisto/2_07/han2_07.pdf

Hedström, Peter, and Petri Ylikoski. 'Causal Mechanisms in the Social Sciences'. Annual Review of Sociology 36 (2010): 49-67.

Koselleck, Reinhart. Futures Past: On the Semantics of Historical Time. Cambridge, MA: MIT Press, 1985.

. 'A Response to Comments on the Geschichtliche Grundbegriffe'. In The Meaning of Historical Terms and Concepts: New Studies on Begriffsgeschichte, edited by Hartmut Lehmann and Melvin Richter, 60-71. Washington, DC: German Historical Institute, 1996.

Koskinen, Inkeri. 'Seemingly Similar Beliefs: A Case Study on Relativistic Research Practices'. Philosophy of the Social Sciences 41 (2011): 84-110.

Kroeber, A. L., and Clyde Kluckhohn. Culture: A Critical Review of Concepts and Definitions. Cambridge, MA: Peabody Museum of American Archaeology and Ethnology, 1952.

Krogerus, Tellervo. Sanottu, tehty. Matti Kuusen elämä 1914-1998 [Said, done. The life of Matti Kuusi 19141998]. Helsinki: Siltala, 2014.

Kuokkanen, Rauna. 'Towards an "Indigenous Paradigm” from a Sami Perspective'. Canadian Journal of Native Studies 20, no. 2 (2000): 411-36. 
Kuorikoski, Jaakko, and Samuli Pöyhönen. 'Looping Kinds and Social Mechanisms'. Sociological Theory 30, no. 3 (2012): 187-205.

Kuper, Adam. Culture: The Anthropologists' Account. Cambridge, MA: Harvard University Press, 1999.

Kupiainen, Jari. 'Varastettu museo, varastettu perinne-Kysymyksiä kulttuuriperinnön suojaamisesta Melanesiassa' [Stolen museum, stolen tradition: how to protect cultural heritage in Melanesia]. Elore 16, no. 1 (2009). http://www.elore.fi/arkisto/1_09/art_kupiainen_1_09.pdf

Kuutma, Kristin. 'Changing Codified Symbols of Identity'. Folklore Fellows' Network 31 (2006): 7-14.

Lukin, Karina. 'Poissaolevan politiikkaa: Historia ja perinteinen kulttuuri nenetsien etnisyyden rakennusaineina' [Politics of the absent. History and traditional culture as ingredients of Nenets ethnicity]. Elore 2 (2005). http://www.elore.fi/arkisto/2_05/luk2_05.pdf

Mahlamäki, Tiina. 'Some Guidelines for the Archiving of Qualitative Research Data'. Folklore Fellows' Network 22 (2001): $2-5$ and 13.

Mallon, Ron. 'Social Construction, Social Roles, and Stability'. In Socializing Metaphysics: The Nature of Social Reality, edited by Frederick F. Schmitt, 327-54. Lanham, MD: Rowman and Littlefield, 2003.

Mathisen, Stein R. 'Folklore in Northern Multicultural Contexts'. Folklore Fellows' Network 32 (2007): 3-9.

Merton, Robert K. 'On Sociological Theories of the Middle Range'. In Social Theory and Social Structure, enlarged ed., 39-72. New York: Free Press, 1968.

O'Giollain, Diarmuid. 'The National and the Local-Practices of De- and Retraditionalization'. Folklore Fellows' Network 28 (2005): 10-13 and 16-18.

Olsen, Kjell. 'The Touristic Construction of the "Emblematic” Sami'. In Creating Diversities: Folklore, Religion and the Politics of Heritage, edited by Anna-Leena Siikala, Barbro Klein, and Stein Mathisen, 292-305. Helsinki: Finnish Literature Society, 2004.

Pöyhönen, Samuli. 'Carving the Mind by its Joints-Natural Kinds and Social Construction in Psychiatry'. In Regarding the Mind-Naturally: Naturalist Approaches to the Sciences of the Mental, edited by Martin Milkowski and Konrad Talmont-Kaminsky, 30-48. Newcastle upon Tyne: Cambridge Scholars, 2013.

Risjord, Mark. 'Ethnography and Culture'. In Philosophy of Anthropology and Sociology, edited by Stephen P. Turner and Mark W. Risjord, 399-428. Amsterdam and Boston: Elsevier/North-Holland, 2007.

Sahlins, Marshall. 'Two or Three Things that I Know about Culture'. Journal of the Royal Anthropological Institute 5, no. 3 (1999): 399-421.

Shuman, Amy, and Galit Hasan-Rokem. 'The Poetics of Folklore'. In A Companion to Folklore, edited by Regina Bendix and Galit Hasan-Rokem, 55-74. Malden: Wiley-Blackwell, 2012.

Siikala, Anna-Leena. 'From Sacrificial Rituals into National Festivals: Post-Soviet Transformations of Udmurt Tradition'. In Folklore, Heritage Politics and Ethnic Diversity: A Festschrift for Barbro Klein, edited by Pertti Anttonen, Anna-Leena Siikala, Stein R. Mathisen, and Leif Magnusson, 57-85. Botkyrka: Multicultural Centre, 2000.

—. 'Mythic Discourses: Questions of Finno-Ugric Studies of Myth'. Folklore Fellows' Network 34 (2008): $3-16$.

Siikala, Anna-Leena, and Jukka Siikala. Return to Culture. Oral Tradition and Society in the Southern Cook Islands. Folklore Fellows' Communications 287. Helsinki: Academia Scientiarum Fennica, 2005.

Strathern, Marilyn. Partial Connections. Updated ed. Walnut Creek, CA: Alta Mira Press, 2004.

Stordahl, Vigdis. 'Nation Building through Knowledge Building: The Discourse of Sami Higher Education and Research in Norway'. In Indigenous Peoples: Self-Determination, Knowledge, Indigeneity, edited by Henry Minde, 249-65. Delft: Eburon, 2008. 
Tuhiwai Smith, Linda. Decolonizing Methodologies: Research and Indigenous Peoples. London and New York: Zed Books; Dunedin, New Zealand: University of Otago Press, 1999.

Virtanen, Pirjo Kristiina. 'Multidimensional Tradition-Native Young People and Their Construction of Indigenousness in Brazilian Amazonia'. Elore 2 (2007). http://www.elore.fi/arkisto/2_07/vip2_07.pdf

Wagner, Roy. The Invention of Culture. Englewood Cliffs, NJ: Prentice-Hall, 1975.

Wilson, William A. Folklore and Nationalism in Modern Finland. Bloomington: Indiana University Press, 1976.

\section{Biographical Note}

Inkeri Koskinen is a PhD student in the Department of Philosophy, History, Culture, and Art Studies at the University of Helsinki, Finland and belongs to the Finnish Centre of Excellence in the Philosophy of the Social Sciences. Her research interests include philosophy of anthropology, philosophy of the humanities, and the use of non-academic knowledge in academic research. 